\title{
Kesulitan Orangtua Mualaf dalam Memberikan Pendidikan Agama Islam kepada Anak Remajanya di Yogyakarta
}

\section{Waenoful}

Guru Pendidikan Agama Islam SMA Pradita Dirgantara

Email: waynopul83@gmail.com

\begin{abstract}
This study aimed to know the level of difficulty of Mualaf parents in giving islamic education to their children, especially their teenagers. The research method used is descriptive qualitative research design. Analysis of the data obtained in this study uses the Content Analysis strategy as a method of analyzing text and language. The result shows that the provision of islamic education toward teenagers is related to the teaching of monotheism, mahdoh worship and ghoiru mahdoh. Difficulties experienced include the lack of Islamic knowledge of parents and the activities of teenagers outside the home make the intensity of parents giving advice to their children less than optimal, teenagers have unstable psychological conditions that make they postpone parents'orders, especially when ordered to perform shalat. Whereas the provision of islamic education to teenagers does not have a negative impact on children's religious behavior, because bringing a private tutor and sending their children to Islamic school are the best solution for Mualaf parents.
\end{abstract}

Keywords: Difficulties, Islamic Education, Mualaf

\section{Pendahuluan}

Pendidikan mempunyai tujuan terbentuknya kepribadian muslim yang berakhlakul karimah. Pendidikan agama Islam berfungsi memelihara dan mengembangkan fitrah sumber daya insani yang ada pada anak menuju kepada terbentuknya manusia seutuhnya (insan kamil) sesuai dengan norma Islam yang diridhai Allah SWT. Sebagai sarana untuk menciptakan generasi muslim yang baik, pendidikan harus diupayakan sedini mungkin. Begitu pentingnya pendidikan, proses pendidikan berlangsung selama seumur hidup, tidak hanya terbatas pada usia tertentu. Dalam hadis Rasulullah SAW disebutkan tuntutlah ilmu dari buaian hingga liang lahat. 


\section{Waenoful}

Proses pendidikan pertama yang dialami manusia terjadi dalam lingkungan keluarga. Orang tua adalah pendidik utama dan pertama dalam hal penanaman keimanan bagi anaknya. Disebut pendidik utama karena besar pengaruhnya dan disebut pendidik pertama karena mereka yang pertama mendidik anaknya (Tafsir, 1995: 8). Anak yang baru dilahirkan mendapatkan pendidikan pertama dari ayahnya dengan dikumandangkannya lantunan adzan dan iqomah di kedua telinganya. Pendidikan keluarga bisa kita sebut dengan pendidikan informal. Menginjak dewasa anak membutuhkan sosialisasi sehingga mulai mengenal lingkungan baru yaitu masyarakat dan sekolah. Pendidikan dalam lingkungan masyarakat disebut pendidikan nonformal sedangkan pendidikan di lingkungan sekolah merupakan pendidikan formal. Lingkungan masyarakat dan sekolah akan mempengaruhi kepribadian anak. Karena anak akan berinteraksi secara langsung dengan orang lain baik anggota masyarakat maupun warga sekolah.

Seiring berjalannya waktu, anak mengalami pertumbuhan dan perkembangan jasmani dan rohani. Saat menginjak remaja, anak mengalami pertumbuhan jasmani secara signifikan. Pertumbuhan jasmani dari luar dan dalam (kelenjar) yang telah matang akan mengakibatkan timbulnya dorongan seks yang perlu mendapatkan perhatian. Dorongan yang bersifat biologis ini menimbulkan kegoncangan emosi, yang dapat mengakibatkan berbagai tindakan, kelakuan, atau sikap yang menjurus ke arah pemuasan dorongan tersebut. Perkembangan jiwa pada masa ini masih labil, meskipun secara biologis telah mencapai kematangan. Oleh karena itu berbagai usaha untuk mengahadapi, membina, dan mengarahkan mereka pada cara hidup yang baik, sesuai dengan ajaran agama masih sangat dibutuhkan dan tidak mudah bagi mereka untuk menerimanya (Arifin, 2008: 65-66).

Suatu keadaan jiwa yang dapat dipastikan tentang remaja adalah penuh kegoncangan. Keadaan seperti itu sangat memerlukan agama dan membutuhkan pegangan atau kekuatan luar yang dapat membantu mereka dalam mengatasi dorongan dan keinginan baru yang 


\section{Kesulitan Orangtua Mualaf ...

belum pernah mereka kenal. Dorongan dan keinginan tersebut seringkali bertentangan dengan nilai-nilai yang dianut orang tua dan lingkungan dimana mereka hidup (Daradjat, 1977: 13). Pada hakikatnya pelaksanaan pendidikan anak merupakan amanat besar dari Allah SWT (Awwad, 1995: 83). Pendidik dalam hal ini orang tua harus serius dan bersungguhsungguh dalam mendidik anak. Firman Allah SWT dalam Al-Qur'an surat At-Tahrim ayat 6 yang artinya "wahai orang-orang yang beriman, jagalah dirimu dan keluargamu dari api neraka...". Menurut Ridwan Malik mengutip pendapat M. Quraish Shihab dalam tafsir AlMisbah yang dimaksud menjaga diri kita dalam ayat ini adalah menjaga istri, anak-anak, dan seluruh anggota keluarga yang berada di bawah tanggung jawab kita, dengan membimbing dan mendidik mereka agar terhindar dari api neraka (Malik, 2013: 21).

Orang tua harus berusaha secara maksimal dan sedini mungkin dalam membimbing anak-anak menuju jalan yang diridhai Allah SWT, dengan memberikan contoh konkret dalam menegakkan ketaatan kepada Allah SWT sepanjang hidup, sebagai upaya memenuhi amanah

Allah SWT untuk menjaga anak-anak sesuai kehendak dan syariat Allah SWT. Rasulullah SAW bersabda "setiap anak dilahirkan dalam keadaan fitrah, maka orang tuanyalah yang menjadikannya Yahudi, Nasrani, atau Majusi." Menurut para ulama, pengertian fitrah dalam hadis tersebut adalah setiap manusia terlahir sesuai dengan prinsip dan karakter yang suci dan bersih. Setiap anak pada dasarnya siap menerima ajaran agama dan kebenaran yang datang dari Allah SWT. Anak terlahir seperti selembar kertas putih yang belum ada noda sama sekali. Hitam-putih perilaku anak-anak ditentukan cara orang tua mendidik sejak kecil. Oleh karena itu pendidikan agama harus diperkenalkan kepada anak-anak sejak dini. Semakin cepat seorang anak mendapatkan pendidikan agama, maka akan semakin baik hasilnya (Malik, 2013: 22).

Anak adalah sosok yang suka meniru. Apa yang dilihat dan didengar biasanya direkam dengan baik oleh anak. Sehingga baik buruknya anggota keluarga dan masyarakat akan 


\section{Waenoful}

mempengaruhi kepribadian anak. Pengaruh lingkungan masyarakat yang baik contohnya aturan-aturan agama berjalan baik, semua orang menjalankan syariat agama, melaksanakan sholat, sering diadakan pengajian dan madrasah diniyah. Contoh pengaruh buruknya adalah lingkungan masyarakat banyak perjudian, banyak orang nakal dan lain sebagainya (Mansur, 2011:363). Melihat hal demikian orang tua perlu mempunyai kewaspadaan dan kebijaksanaan dalam mendidik anak. Keteladanan orang tua merupakan harga mati yang tidak bisa ditawar dalam mendidik anak-anak. Keteladanan berupa sikap dan tingkah laku anggota keluarga dirumah, terutama ayah dan ibu, menjadi faktor yang paling menentukan karakter anak-anak daripada ajaran-ajaran moral yang hanya disampaikan lewat lisan atau perintah. Oleh karena itu sudah sepantasnya orang tua berusaha memanfaatkan waktu terbaik di rumah dengan membangun komunikasi dan interaksi yang positif dengan anak-anak. Terutama dengan memberikan teladan atau menjadi model lewat sikap, tutur kata, dan perbuatan yang bisa mereka jadikan contoh terbaik atau uswatun khasanah dalam perkembangan hidup mereka. Sudah seyogyanya menjadikan rumah sebagai madrasah, tempat menghidupkan nilai-nilai dan praktek keagamaan yang baik dan benar.

Orang tua harus sudah mempunyai ilmu agama yang luas dan baik untuk mengajar dan mendidik anak. Tanpa adanya bekal ilmu agama orang tua akan menemukan kesulitan dan hambatan mendidik anak. Jika orang tua masih sedikit ilmu agamanya, bagaimana mungkin bisa mendidik dan mengajar agama bagi anak-anaknya. Kondisi demikian akan mengakibatkan kurang maksimalnya pendidikan agama bagi anak dalam keluarga. Orang tua yang mempunyai kondisi demikian masih beruntung karena masih ada lingkungan masyarakat dan sekolah yang dapat mendukung pendidikan agama anak. Meskipun dapat terbantu oleh lingkungan masyarakat dan sekolah, pendidikan agama yang utama ada di tangan orang tua. Karena model mendidik yang tepat bagi anak-anak adalah orang tua menjadi panutan atau suri tauladan, orang tua sebagai tempat meniru dalam berperilaku. 


\section{Kesulitan Orangtua Mualaf ...

Yogyakarta merupakan tempat yang multikultural. Banyak beragam tradisi, budaya dan agama. Terdapat banyak agama yang dianut oleh masyarakat. Ada dua agama mayoritas yaitu Islam dan Kristen. Di Yogyakarta antar umat beragama dapat berbaur hidup bersama dalam masyarakat yang aman, damai dan adil. Masing-masing penganut agama dapat dengan bebas melaksanakan kegiatan ibadahnya. Dampak dari sosialisasi antar umat beragama, sesorang berinteraksi dengan orang yang berbeda agama. Hal ini menyebabkan sesorang berpindah agama, khususnya berpindah agama menjadi muslim atau kita kenal menjadi mualaf. Fenomena seseorang menjadi mualaf sering terjadi di Yogyakarta. Para aktivis dakwah Islam melihat kondisi demikian dan membentuk wadah pembinaan para mualaf. Wadah pembinaan para mualaf meliputi: Majelis Muhtadin Yogyakarta, Mualaf Center Yogyakarta, dan Yayasan Ukhuwah Mualaf. Majelis-majelis ini tempat berkumpulnya para mualaf yang bersungguh-sungguh mempelajari dan mendalami agama Islam. Para mualaf dibina dan dibimbing agar senantiasa istiqomah di jalan agama yang baru dianutnya yaitu Islam.

Mualaf adalah istilah bagi orang yang pindah agama dari non muslim menjadi muslim. Seorang mualaf tentu masih sedikit pengetahuan dan keterampilan ibadahnya. Berbeda dengan orang yang sejak kecil sudah memeluk Islam. Hal ini menjadi faktor penghambat proses pendidikan agama Islam bagi anak dalam keluarga. Hal tersebut mengindikasikan orang tua mengalami kesulitan dalam praktek pendidikan agama Islam kepada anaknya. Oleh karena itu dengan adanya fenomena tersebut penulis terinspirasi dan tergugah untuk meneliti fenomena tersebut dalam bentuk karya ilmiah yang berjudul "Kesulitan Orangtua Mualaf dalam Memberikan Pendidikan Agama Islam kepada Anak Remajanya di Yogyakarta”.

Pendidikan bagi anak merupakan hal yang penting untuk diperhatikan oleh orang tua. Pendidikan merupakan sarana untuk membentuk manusia yang seutuhnya. Artinya melalui pendidikan anak dibentuk untuk menjadi manusia yang berakhlak mulia sesuai 
dengan ajaran syariat agama Islam. Keluarga merupakan lingkungan pertama kali anak mendapatkan pendidikan. Sejak lahir anak sudah mendapatkan pendidikan tauhid dengan dikumandangkannya lantunan adzan di telinga anak. Lingkungan keluarga menjadi tempat anak belajar banyak hal. Orang tua perlu mengutamakan mengajarkan pendidikan agama Islam kepada anaknya. Pendidikan agama Islam merupakan pendidikan yang utama bagi anak karena sebagai dasar keimanan anak. Pendidikan agama harus diajarkan kepada anak sejak usia dini agar anak sudah mengenal agamanya dan mempunyai keimanan yang kuat. Karena hal tersebut sangat berpengaruh pada perilaku keagamaan anak pada usia remaja.

Keberhasilan pendidikan agama di waktu usia dini akan berdampak pada sikap dan tingkah laku anak ketika menginjak remaja. Pendidikan agama yang berhasil akan membentuk akhlak anak yang baik, begitu juga sebaliknya. Dalam hal ini orang tua mempunyai peran yang strategis dalam mengajarkan pendidikan agama kepada anak. Perlu langkah yang kreatif dan serius dalam mendidik agama kepada anak agar tujuan pendidikan dapat tercapai. Pendidikan agama dalam keluarga merupakan kewajiban bagi setiap orang tua tidak terkecuali orang tua mualaf. Orang tua mualaf yang mempunyai masa lalu berkeyakinan bukan Islam dan mempunyai kekurangan dalam hal pengetahuan agama Islam, praktik ibadah, membaca Al-Qu'an, dan lain-lain pun wajib mengajarkan pendidikan agama Islam kepada anaknya. Hal tersebut akan berdampak pada proses orang tua mualaf dalam mengajarkan pendidikan agama Islam kepada anaknya.

Berdasarkan latar belakang yang telah dijelaskan pada bab sebelumnya, peneliti akan menganalisi mengenai proses pelaksanaan orang tua mualaf memberikan pendidikan agama Islam kepada anak remajanya, kesuliatan yang ada pada proses pemberian pendidikan agama Islam oleh orang tua mualaf kepada anak remajanya, dan implikasinya terhadap perilaku keagamaan anak. 


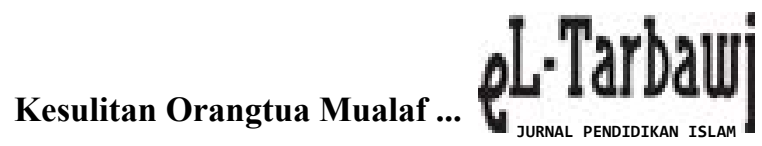

\section{Hasil dan Pembahasan}

Metode yang Digunakan Orang Tua Mualaf dalam Memberikan Pendidikan Agama Islam Kepada Anak Remajanya.

Dalam menyampaikan materi pendidikan agama Islam, orang tua perlu menggunakan metode yang tepat agar materi yang diajarkan dapat dipahami oleh anak. Terdapat banyak metode mendidik yang dicontohkan Rasulullah SAW. Metode yang digunakan Rasulullah seperti keteladanan dan akhlak mulia, berdialog, pembiasaan, memotivasi/nasehat, bercerita/ kisah. Metode yang digunakan orang tua mualaf dalam memberikan pendidikan agama Islam kepada anaknya yaitu sebagai berikut:

\section{Keluarga Ibu Cicilia}

Berikut ini peneliti sajikan hasil wawancara dengan Ibu Cicilia tentang metode yang digunakan Ibu Cicilia dalam memberikan pendidikan agama Islam kepada anaknya bagi Ibu Cicilia Pendidikan untuk anak-anaknya sangatlah penting (Wawancara, 31 Desember 2015). Termasuk di dalamnya yaitu pendidikan agama Islam. Dengan pendidikan yang baik akan membawa anak kepada masa depan yang cerah. Masa depan anak harus lebih baik dari pada orang tuanya. Menurutnya, pendidikan agama Islam wajib diajarkan kepada anak agar anak memiliki kepribadian dan sikap yang baik. Dasar keimanan yang kuat akan menjadikan anak selalu berhatihati dalam bertutur kata dan bertindak. Sadar dengan statusnya sebagai seorang mualaf, Ibu Cicilia sangat mengutamakan pendidikan agama Islam kepada anakanya. Ada yang beliau tidak bisa ajarkan kepada anaknya sehingga sejak kecil anaknya dididik dilingkungan yang Islami. Waktu kecil anaknya di masukkan ke Taman Pendidikan Al-Qur'an (TPA). Saat anak memasuki usia SMP, beliau memasukkan anaknya sekolah di SMP Muhammadiyah. Tujuannya agar anak mendapatkan pendidikan agama Islam yang baik. 


\section{Waenoful}

Cara atau metode yang digunakan Ibu Cicilia dalam mengajarkan pendidikan agama Islam kepada anaknya adalah dengan teladan atau memberikan contoh dan nasihat. Metode keteladanan merupakan cara memberikan contoh perilaku yang baik kepada anak sehingga anak dapat menerapkannya dalam kehidupan sehari-hari. Keteladanan merupakan metode yang sering digunakan orang tua dalam mendidik anak. Dalam mendidik anaknya ibu Cicilia tidak hanya menyuruh anaknya untuk melakukan suatu hal baik seperti ibadah sholat, puasa tetapi beliau memberi contoh langsung dengan perbuatan. Setiap kali ada pengajian, beliau mengajak anaknya untuk mengikuti pengajian dengan tujuan menambah wawasan agama anak. Ibu Cicilia juga mengajak anaknya mengikuti kegiatan tadarus Al-Qur'an yang dilakukan setiapa malam minggu di masjid kampung. Tidak hanya dalam hal ibadah, Ibu Cicilia menganggap penanaman akhlakul karimah kepada anak sangat penting. Ibu Cicilia selalu berperilaku baik dan menunjukkan sikap yang sopan dan santun agar bisa dicontoh anaknya. Orang tua mendidik anaknya agar menjadi manusia yang mempunyai karakter yang baik. Contohnya dalam hal berbicara kepada orang yang lebih tua.

Masa remaja merupakan masa peralihan anak-anak menuju dewasa. Kondisi anak masih labil dan lebih banyak berinteraksi dan percaya dengan temannya. Banyak hal baru yang belum pernah dijumpai pada masa anak-anak. Remaja selalu merasa penasaran dengan hal-hal yang baru tersebut. Tidak memikirkan dampak dari tindakannya. Oleh karena itu orang tua harus ekstra dalam memberika pendidikan kepada anaknya. Agar anak tidak terjerumus pada tindakan-tindakan yang negatif. Menyikapi sikap remaja yang banyak mengarah pada tindakan negatif, Ibu Cicilia sangat memperhatikan perkembangan anaknya. Ibu Cicilia salah satu orang tua yang memberikan fasilitas yang terbatas kepada anaknya. Seperti handphone yang diberikan kepada anaknya adalah handphone tipe lama. Hal tersebut dilakukan 


\section{Kesulitan Orangtua Mualaf ...

untuk mendidik anak dalam kesederhanaan dan untuk mencegah anak melakukan tindakan negatif di dunia maya. Karena dengan handphone yang mempunyai fitur yang canggih dapat memancing anak untuk melakukan hal negatif seperti membuka situs porno dan lain-lain. Ibu Cicilia mengatakan bahwa "yang penting bisa buat telfon sama sms mas", nanti kalo Hpnya bagus si Taufiq bisa macem-macem lihat gambar-gambar porno dan lain-lain yang mengarah ke hal negatif'.

Untuk memastikan aktivitas keseharian anaknya, Ibu Cicilia menyempatkan mengecek handphone anaknya saat anaknya tertidur. Hal tersebut dilakukan untuk memastikan tidak ada kegiatan anaknya yang negatif atau nyeleneh seperti pacaran. Tidak hanya dengan cara keteladanan dan pengawasan, Ibu Cicilia menggunakan cara nasihat dalam memberikan pendidikan agama Islam kepada anaknya. Saat ada kesempatan kumpul bersama anak, Ibu Cicilia menyempatkan untuk menasihati anaknya. Pada waktu belajar pun Ibu Cicilia selalu mengingatkan anaknya untuk tekun belajar agar dapat mencapai prestasi terbaik di sekolah.

\section{Keluarga Ibu Irene}

Berdasarkan hasil wawancara penulis dengan Ibu Irene didapatkan data tentang metode yang digunakan Ibu Irene dalam memberikan pendidikan agama Islam kepada anaknya yang remaja yakni sebagai berikut (Wawancara, 15 Januari 2016). Keluarga Ibu Irene merupakan keluarga yang berpendidikan. Menurut Ibu Irene pendidikan yang baik perlu diajarkan kepada anaknya sejak dini agar anak dapat tumbuh menjadi manusia yang berakhlak baik dan berpengetahuan luas. Sebagai seorang mualaf Ibu Irene belum banyak menguasai pengetahuan tentang Islam dan pengetahuan praktik ibadah. Suaminya bukan Islam yang taat sehingga belum bisa mengajarinya Islam. Kondisi yang penuh keterbatasan, dalam mendidik agama Islam kepada anaknya Ibu Irene memilih cara mengundang guru ngaji ke rumah. Tujuannya untuk membantunya 


\section{Waenoful}

mengajarkan agama Islam kepada anaknya dan beliau pun ikut belajar Islam bersama guru ngaji anaknya.

Ibu Irene sangat serius dalam hal mendidik anak. Sejak kecil anaknya dididik dengan penuh kasih sayang dan perhatian. menurutnya kepandaian anak didapat dari kasih sayang orang tua. Beliau mendidik anak degan cara pembiasaan. Sejak kecil anak dibiasakan untuk selalu berdo'a kepada Allah. Beliau mengatakan "mas, anakanak sudah saya ajarkan, kalo minta apa-apa sama Allah, pasti dikabulkan. Saya ajak mereka bangun malam untuk tahajud dan berdo'a apa yang mereka inginkan". Ibu Irene sengaja melakukan hal tersebut untuk menanamkan keimanan kepada anaknya. Menurutnya keimanan perlu ditanamkan kepada anak sejak dini. Ibu Irene tidak lupa mengajak anaknya sholat berjamaah di rumah. Karena masjid jauh dari rumah sehingga sholat jamaahnya di rumah. Menurutnya, mengajarkan ibadah harus menggunakan metode mengajak anak beribadah bersama. $\mathrm{Bu}$ Irene mengatakan: "nggak bisa asal suruh mas, kita sebagai orang tua harus ngasih contoh. InsyaAllah kalau anak diajak beribadah bareng pasti mau, nggak nolak".

Bercerita salah satu cara yang digunakan Ibu Irene dalam mendidik anaknya saat masih kecil. saat persiapan tidur dan kondisi anak masih "tidur ayam" atau setengah tidur setengah melek beliau menceritakan kisah penuh hikmah kepada anaknya. menceritakan kisah bertujuan agar anak meniru perilaku dan sikap baik yang ada dalam tokoh cerita dan tidak meniru sikap tercela yang ada pada tokoh cerita. Ibu Irene sangat dekat dengan anak-anaknya. setiap kesempatan kumpul bersama anakanaknya beliau sempatkan mengobrol dengan anak-anaknya. obrolannya penuh dengan nasihat. Seperti saat sarapan pagi dan kumpul sore sambil minum teh bareng adalah kesempatan Ibu Irene untuk mengobrol dengan anaknya. Ibu Irene selalu menyambut anaknya di ruang tamu saat jam pulang sekolah. Saat anak sampai di 


\section{Kesulitan Orangtua Mualaf ...

rumah beliau menanyakan apa saja kejadian yang ada di sekolah selama seharian. Ketika beliau sakit dan tidak bisa menyambut anaknya. pasti saat anak pulang yang dicari pertama kali adalah ibunya. anakanya tanya: "ibu gak mau ndengerin ceritaku di sekolah hari ini? Ibunya menjawab "ibu, lagi nggak enak badan, ceritanya nanti saja yah".

Memberikan perhatian dan kasih sayang metode dan cara yang digunakan Ibu Irene. Beliau membuat anaknya mempunyai keyakinan bahwa orang tuanya orang yang paling dipercayai. Dengan anak rajin bercerita kepada ibunya membuat anak menjadi anak yang terbuka. Menurut Ibu Irene: "mas, kalo anak kurang perhatian di rumah, mereka akan mencari perhatian di luar”. Oleh karena itu beliau sangat perhatian dengan anak-anaknya. Ibu Irene selalu berpesan kepada anaknya. nasihatnya adalah "berperilaku baik dimanapun kamu berada, dan buatlah lingkungan yang sedang kau berada menjadi lebih baik. Nasihat tersebut akan membuat anak menjaga tingkah laku dan sikapnya dimanpun anak berada. Senantiasa membuat kebaikan untuk kondisi lingkungan yang lebih baik.

\section{Keluarga Ibu Maria}

Berdasarkan hasil wawancara dengan Ibu Maria didapatkan data tentang metode yang digunakan Ibu Maria delam memberikan pendidikan agama Islam kepada anaknya yang remaja sebagai berikut (Wawancara, 18 Januari 2016). Dari kecil Ibu Maria dididik dalam keluarga Katolik taat. Menginjak usia dewasa ketaatannya masih konsisten. Ketaatannya pada agamanya menumbuhkan benih keraguan terhadap keyakinannya selama ini tentang perjalanan ruh setelah mati. Keraguannya mengantarkan Ibu Maria menemukan jalan hidayah dan mendapatkan cahaya Islam. Karakter taat terhadap agama masih tertanam kuat dalam dirinya meskipun sudah memeluk Islam. 


\section{Waenoful}

Dalam mendidik agama Islam kepada anak, Ibu Maria termasuk orang tua yang serius. Metode pembiasaan beliau terapkan dalam meltih anak-anaknya beribadah dengan mebiasakan anak beribadah sejak usia dini. Saat usia 5 tahun anak diajarkan puasa wajib di bulan Ramadhan satu bulan penuh. Mewajibkan sholat berjamaah di masjid atau mushola bagi anak laik-lakinya. Jika anak membangkang, Ibu Maria tidak segan-segan memukul anaknya dengan sapu, tongkat atau barang yang bisa digunakan untuk memukul. Menurut beliau memukul cara yang diajarkan Rasulullah SAW.

Anak-anak sering diajak pengajian bersama untuk menambah pengetahun keIslamannya. Jika anak masih bingung maka beliau menjelaskannya saat di rumah. Mengajak berarti memberikan contoh kepada anak. Anak menjadi lebih semangat dan mau untuk melakukan perintah orang tua. Selain keteladanan Ibu Maria juga mengajarkan doktrin kepada anaknya seperti tidak boleh mengambil barang atau sesuatu yang bukan haknya. Pohon yang ada dijalan pun tidak boleh anak mengambilnya. Pernah suatu ketika anaknya mengambil jambu di sawah. Ibu Maria mengetahui perbuatan anaknya, langsung beliau menyuruh anaknya untuk mengembalikan jambunya kepada yang punya pohon jambu. Menurut Ibu Maria anak perlu diajarkan seperti itu agar saat dewasa menjadi manusia yang pekerja keras dan tanggung jawab.

Anak-anaknya yang masih belum dewasa tidak diperbolehkan memiliki handphone sendiri. Alasan Ibu Maria agar anak tidak melakukan hal-hal yang negatif dan fokus belajar. Ketika anak-anak ingin berkomunikasi dengan temannya, anak langsung pinjam handphone atau minta tolong kepada beliau untuk sekedar mengirim sms kepada temannya. Anak-anaknya juga dibatasi menyaksikan acara TV. Keluarga Ibu Maria hanya memiliki satu TV dan itupun ditaruh di kamar beliau sehingga anak 


\section{Kesulitan Orangtua Mualaf ...

masih dalam pengawasan saat nonton TV. Menurut beliau Hal demikian dilakukan agar anak-anak tidak menyaksikan tayangan yang negatif yang bisa berdampak pada pertumbuhan karakternya. Begitu tegas dan hati-hati Ibu Maria dalam mendidik anaknya. Kata Ibu Maria: "mas, saya lebih baik berdoa kepada Allah SWT agar anaknya buta daripada anaknya melihat hal negatif yang tidak boleh dilihat anaknya". Ibu Maria juga mengajarkan kepada anaknya untuk tidak hidup boros. Anak-anaknya diajarkan untuk tidak jajan sembarangan di luar. Ketika anaknya ingin makan bakso Ibu Maria lebih memilih buat baso sendiri agar hemat dan kehalalannya terjamin. Menurut beliau Makan bersama di rumah dapat mempererat rasa kekeluargaan.

Saat anak minta dibelikan sesuatu selalu tanya terlebih dahulu kepada beliau “ibu ada uang nggak buat beli ini”? kalau ada uang dan sekiranya barang tersebut penting untuk anaknya Ibu Maria membelikannya. Jika sebaliknya maka Ibu Maria tidak akan membelikannya. Sejak dini anak-anak juga diajarkan hidup mandiri. Saat ibu maria masak, beliau mengajak anak-anaknya membantu memasak agar kelak anaknya bisa memasak. Walaupun anak laki-laki beliau tetap mengajarkan masak. Tidak hanya pelajaran memasak, beliau juga mengajarkan anaknya menjahit dan hal lain yang bermanfaat bagi kehidupan anaknya dimasa depan. Ibu Maria selalu menjaga komunikasi dengan anak-anaknya. hal ini penting menurutnya karena sebagai sarana pengawasan terhadap anak. dengan komunikasi orang tua dapat mengetahui apa yang dilakukan dan dialami anaknya. Anak-anak dibiasakan untuk suka membaca. Sebulan sekali Ibu Maria mengajak anak-anaknya pergi ke Social Agency untuk membeli buku bacaan. Anak-anak diberi kebebasan memilih buku sesuai seleranya tapi bukubuku yang islami dan mengandung ilmu pengetahuan.

Ibu maria tidak menggunakan iming-iming hadiah duniawi kepada anaknya jika melakukan hal kebaikan. Beliau menjanjikan bahwasanya jika anaknya taat 


\section{Waenoful}

beribadah dan berbuat baik akan dibalas pahala Allah SWT. Dengan demikian akan tumbuh dalam hati anak niat yang tulus ikhlas beribadah dan berbuat baik hanya karena Allah SWT. Cara ini merupakan salah satu menanamkan tauhid pada anak. Dari penjelasan di atas tentang metode atau cara yang digunakan orang tua mualaf dalam memberikan pendidikan agama Islam kepada anaknya dapat diketahui bahwa para orang tua mualaf menggunakan metode atau cara memberikan contoh atau keteladanan, pembiasaan, pemberian nasihat, dan menceritakan kisah. Memberi contoh atau keteladanan merupakan cara yang efektif dalam mendidik anak. dengan mengajak beribadah bersama membuat anak tidak merasa disuruh sehingga dengan suka rela mau mengerjakan perintah orang tuanya.

Pembiasaan akan menghasilkan kebiasaan. Kebiasaan akan menjadi sikap atau perilaku. Pembiasaan hal baik yang dilakukan anak akan membentuk sikap dan perilaku anak yang baik. Pembiasaan akan berhasil jika dilakukan anak sejak usia anak dini. Karena sudah tertanam kuat di hati anak sejak usia dini sehingga saat anak beranjak remaja pembiasaan tersebut tetap dilakukan. Anak diibaratkan gelas kosong yang wajib diisi segala yang baik oleh orang tuanya. Anak diibaratkan selembar kertas putih kosong yang wajib diwarnai oleh orang tuanya dengan segala hal yang berguna bagi masa depannya. Nasihat-nasihat orang tua sangat diiperlukan anak. anak adalah sosok orang yang masih belum berpengalaman sehingga berbuat kesalahan adalah kewajaran. Tugas orang tua memberi nasihat dan mengarahkannya agar tidak mengulang kesalahannya dan dapat melakukan hal yang lebih baik. Pemberian nasihat perlu dilakukan dengan penuh perhatian dan kasih sayang agar nasihat dapat dipahami dan di menegerti anak. Fitrah anak adalah mendapatkan perhatian dan kasih sayang dari orang tuanya. Metode cerita sangat efektif untuk menanamkan nilai-nilai dan karakter yang baik. Anak dapat dengan mudah memahami pesan yang ingin disampaikan orang tua kepadanya. Cerita menjadikan anak belajar menjadi 


\section{Kesulitan Orangtua Mualaf ...

pendengar yang baik dan menghargai orang lain. Cerita yang dikemas akan lebih menarik perhatian anak daripada nasihat secara langsung.

Orang tua mualaf yang sudah mapan keIslamannya sangat hati-hati dalam mengajarkan pendidikan agama Islam kepada anaknya dan lebih bersikap keras daripada orang tua mualaf yang belum mapan keIslamannya. Orang tua mualaf yang sudah mapan keIslamannya tidak segan memukul jika anaknya tidak shalat, tidak memberikan fasililitas handphone kepada anaknya, dan jika anaknya melakukan pelanggaran atau kemaksiatan, orang tua mualaf lebih memilih mendoakan anaknya buta dariapada anaknya melakukan zinah mata. Sedangkan orang tua mualaf yang belum mapan keIslamannya dalam mengajarkan pendidikan agama Islam kepada anaknya lebih sering menggunakan metode nasihat dengan kasih sayang dan penuh perhatian.

\section{Materi Pendidikan Agama Islam yang Diajarkan Orang Tua Mualaf Kepada Anak Reamajanya}

Materi pendidikan agama Islam dalam keluarga biasanya dalam bentuk mengajarkan dan mencontohkan kepada anak tentang ajaran-ajaran Islam seperti tauhid, rukun iman, rukun Islam, akhlaq, budi pekerti, dan sosial. Orang tua mengajarkan membaca Al-Qur'an, mendirikan sholat, adat sopan santun terhadap yang lebih tua, adat bergaul dengan teman, dan lain sebagainya. Berikut materi pendidikan agama Islam yang diajarkan orang tua mualaf kepada anaknya:

\section{Keluarga Ibu Cicilia}

Berdasarkan hasil wawancara penulis dengan Ibu Cicilia tentang materi yang Ibu Cicilia ajarkan kepada anak reamajanya didapatkan data sebagai berikut (Wawancara, 31 Desember 2015). Dalam kondisi keterbatasannya Ibu Cicilia tetap 


\section{Waenoful}

semangat dalam memberikan pendidikan agama Islam kepada anaknya. masalah akhlaq anak sangat Ibu Cicilia perhatikan. Beliau mengajarkan kepada anaknya akhlaq yang baik sesuai yang dicontohkan Nabi Muhammad SAW. Contohnya dalam interaksi antar anggota keluarga, tetangga dan warga sekitar agar selalu menjaga adat sopan santun dalam berbicara kepada yang lebih tua. Ibu Cicilia selalu berpesan kepada anaknya agar tidak menjadi anak yang ugal-ugalan, merokok, minum alkohol, dan hal negatif lainnya. Senantiasa mengajak anak-anak untuk sholat berjamaah di masjid. Hal ini menjadi perhatian Ibu Cicilia agar anaknya tetap menjaga sholat lima waktunya. Walaupun anaknya dalam kondisi kelelahan setelah aktivitas di sekolah, Ibu Cicilia senantiasa mengingatkan anaknya untuk sholat.

Mengajarkan pengetahuan tentang agama Islam. Hal ini tidak beliau langsung yang mengajari namun dengan cara mengajak anak ke tempat pengajian yang beliau inkuti. Karena pengetahuan agama Ibu Cicilia masih sedikit sehingga untuk memudahkan beliau mengajarkan agama Islam kepada anaknya dengan cara mengajak bersama belajar di pengajian. Setiap malam minggu Ibu Cicilia mengajak anaknya tadarus Al-Qur'an di masjid kampung. Ibu Cicilia belum lancar membaca Al-Qur'an sehingga beliau belum mampu secara mandiri mengajarkan Al+qur'an kepada anaknya. agar anaknya tetap bisa belajar Al-Qur'an adalah dengan cara mengajaknya ke tadarus Al-Qur'an di masjid kampung. Pengalaman beliau yang pernah memeluk agama Katolik membuatnya menekankan keimanan yang kuat pada anaknya agar kelak anaknya tetap dalam iman Islam.

\section{Keluarga Ibu Irene}

Berdasarkan hasil wawancara penulis dengan Ibu Irene tentang materi yang Ibu Irene ajarkan kepada anak reamajanya didapatkan data sebagai berikut (Wawancara, 15 Januari 2016). Hal pertama yang Ibu Irene ajarkan kepada anaknya 


\section{Kesulitan Orangtua Mualaf ...

adalah tentang ketauhidan atau aqidah. Beliau membiasakan anak-anaknya untuk memohon dan meminta segala keinginan. Contohnya saat anak pertamanya iri melihat teman-temannya yang sudah punya adik. Ibu Irene berbicara kepada anaknya untuk berdoa dan minta sama Allah SWT. Selang beberapa bulan doanya terkabul akhirnya punya adek. Lalu Ibu Irene menjelaskan kepada anak pertamnya bahwa doa anaknya dikabulkan oleh Allah SWT, makanya saat ada keinginan mintalah sama Allah dengan sungguh-sungguh dan hanya kepada Allah meminta segala sesuatu. Sejak kecil hati anak sudah tertanam ketauhidan atas kekuasaan Allah SWT. Ketidakbisaan Ibu Irene dalam ngaji atau membaca Al-Qur'an tidak membuat beliau tidak mengajarkan Al-Qur'an kepada anaknya. Ibu Irene mengundang guru ngaji ke rumah untuk mengajarkan baca tulis Al-Qur'an dan pelajaran agama Islam kepada anak. Justru Ibu Irene belajar bersama anaknya membaca Al-Qur’an.

Dalam hal sholat, Ibu Irene selalu mengajak sholat wajib secara berjamaah di rumah. Ditengah malampun Ibu Irene membiasakan anaknya untuk bangun dan menunaikan sholat malam. Saat hari senin dan kamis setelahsholat malam dilanjutkan makan sahur untuk puasa sunah senin dan kamis. Sejak kecil anak Ibu Irene di ajarkan untuk menghargai dan menghormati orang lain. Beliau mengajarkan anaknya untuk tidak selalu menyuruh asisten rumah tangga. Jika ada hal yang diinginkan anak dan masih bisa dilakukan sendiri maka anak harus melakukannya sendiri. Jika ada suatu hal yang tidak bisa dilakukan sendiri oleh anak dan harus meminta pertolongan asisten rumah tangga maka boleh sang anak minta tolong. Itu pun harus dilakukan dengan penuh sopan santun tidak asal suruh. Menurutnya, beliau ajarkan anak untuk minta tolong asisten rumah tangga dengan kata seperti ini: "mbak, kalo mbak gak keberatan aku boleh minta tolong?". Anak diajarkan sopan santun kepada semua orang tidak memandang status orang tersebut. 


\section{Waenoful}

Akhlak dan karakter anak menjadi perhatian Ibu Irene. Beliau sering menasihati anaknya untuk senantiasa berbuat kebaikan dan membuat lingkungan dimana anaknya berada menjadi lebih baik. Menurut beliau, tolak ukur keberhasilan orang tua dalam mendidik anak dapat dilihat dari akhlaq anak. jika akhlaq anak baik, maka orang tua nya sudah berhasil mendidik. Jika sebaiknya maka orang tua belum bisa mendidik anaknya.

\section{Keluarga Ibu Maria}

Berdasarkan hasil wawancara penulis dengan Ibu Irene tentang materi yang Ibu Irene ajarkan kepada anak reamajanya didapatkan data sebagai berikut (Wawancara, 18 januari 2016). Katauhidan adalah hal yang utama bagi Ibu Maria untuk diajarkan kepada anaknya. anaknya harus mempunyai ketauhidan atau keimanan yang kuat. Menurut beliau jika ketauhidan sudah baik dan benar maka hal lain akan mengikuti seperti akhlaq dan ibadah anaknya. Segala ketentuan syariat dalam agama Islam untuk selalu dipatuhi dan diyakini dengan sungguh-sungguh. Beliau menanamkan tauhid dan keimanan yang kuat kepada anak-anaknya. mengenalkan pengetahuan agama selain Islam sebagai perbandingan untuk menguatkan aqidah anak-anaknya. Ibu Maria juga mengajarkan ibadah-ibadah sehari-hari baik yang wajib maupun sunah. Saat anak masih usia 5 tahun diajari untuk puasa satu bulan penuh. Anak-anak juga diajarkan dan dibiasakan sholat berjamaah di masjid.

Merasa masih belum baik bacaan Al-Qur'annya Ibu Maria tetap mengajarkan ngaji Al-Qur'an pada anak-anaknya dengan mengundang guru ngaji ke rumah untuk mengajari ngaji anak-anaknya. kesibukan beliau menjadi seorang guru yang mempunyai banyak tugas sehingga perlu pengganti dirinya mendampingi anak dalam belajar ngaji dan belajar agama Islam. Masalah halal dan haram sudah Ibu Maria ajarkan sejak dini. Beliau memberikan doktrin kepada anaknya bahwa barang atau 


\section{Kesulitan Orangtua Mualaf ...

sesuatu yang bukan miliknya haram untuk diambil. Seperti daun yang ada di pohon bukan miliknya dan batu yang ada dijalan tidak boleh diambil karena bukan milik kita. Beliau juga mengajarkan untuk makan makanan yang halal lagi baik. Tidak menyuruh membeli makanan atau jajan di luar sembarangan karena belum kelas kehalalannya seperti baso yang di jual keliling. Ibu Maria juga melarang anaknya memakan makanan yang di dapat dari acar kenduri tetangganya. Seenak apapun makanan itu, anak tidak boleh memakannya. Lebih baik untuk ayam peliharaannya. Karena menurutnya kenduri bukan ajaran Islam. Tidak lupa Ibu Maria mengajarkan pergaulan anaknya dengan teman sebayanya dan lingkungan sekitar rumah. Beliau mengajarkan antara laki-laki dan perempuan yang bukan mahramnya tidak boleh bersama-sama. Tidak boleh boncengan. Anaknya juga tidak diberi handphone karena untuk menjaga pergaulan anaknya agar tetap dalam koridor pergaulan yang baik. Ibu Maria mengajarkan anaknya untuk bersosialisasi dengan masyarakat sekitar rumah denga aktif dalam kegitan pemuda di kampungnya agar anak dapat bersosialisasi dengan orang lain dan dapat pengalaman.

Dari penjelasan di atas tentang materi pendidikan agama Islam yang diajarkan orang tua mualaf kepada anaknya dapat diketahui bahwa anak diajari tentang ketauhidan, aqidah atau keimanan kepada Allah SWT. Hal ini dijadikan sebagai dasar atau landasan agar anak tidak melakukan hal yang menyimpang dari syariat agama Islam. Setelah anak diajarkan tentang ketauhidan selanjutnya orang tua mengajarkan dan membiasakan untuk mematuhi segala ketentuan syariat Islam seperti tentang halal dan haram, menunaikan ibadah wajib dan sunah seperti sholat wajib lima waktu, sholat malam, sholat dhuha, puasa wajib, puasa sunah senin dan kamis, ngaji atau membaca Al-Qur'an. Segala aktivitas ibadah dilakukan sebagai pelaksanaan dalam menaati aturan agama Islam. Orang tua mualaf juga mengajarkan akhlaqul karimah atau perilaku terpuji kepada anaknya. karena akhlaq merupakan 


\section{Waenoful}

hal pokok yang wajib diajarkan dalam agama Islam. Inti dari pendidikan adalah agar anak mempunyai karakter dan perilaku yang baik. Tentunya perilaku terhadap Tuhan dan sesamanya juga dengan alam. Termasuk di dalamnya cara pergaulan dengan sesamanya yang sesuai dengan syariat Islam.

Orang tua mualaf yang sudah mapan keIslamannya dalam mengajarkan materi pendidikan agama Islam lebih menekankan masalah ketauhidan daripada orang tua mualaf yang belum mapan keIslamannya. Orang tua mualaf yang sudah mapan keIslamannya sangat memparhatikan masalah ketauhidan. Dalam hal sepele pun anaknya diajarkan masalah ketauhidan seperti diajarkan untuk tidak sembarang mengambil barang yang bukan miliknya walaupun benda tersebut hanya selembar daun atau batu di jalan. Jika anaknya melakukan kebaikan, orang tua mualaf mengajarkan anaknya untuk tidak mengharapkan hadiah dalam bentuk benda, tetapi mengajarkan bahwa segala sesuatu yang dilakukan semata-mata kerana Allah SWT. Sedangkan orang tua mualaf yang belum mapan keIslamannya selain mengajarkan ketauhidan, dan juga mengutamakan mengajarkan akhlak dan perilaku yang baik kepada anaknya.

\section{Kesulitan Orang Tua Mualaf Dalam Menggunakan Metode Yang Digunakan Dalam Memberikan Pendidikan Agama Islam Kepada Anaknya}

Orang tua mualaf tidak selalu dengan mudah dalam memberikan pendidikan agama Islam kepada anaknya. Ada kesulitan atau hambatan yang dialami orang tua mualaf. Berikut kesulitan atau hambatan yang dialami orang tua mualaf dalam memberikan pendidikan agama Islam kepada anaknya:

\section{Keluarga Ibu Cicilia}




\section{Kesulitan Orangtua Mualaf ...

Berdasarkan hasil wawancara penulis dengan Ibu Cicilia tentang kesulitan dalam metode yang Ibu Cicilia gunakan dalam mengajarkan pendidikan agama Islam kepada anak reamajanya sebagi berikut (Wawancara, 31 Desember 2015). Aktivitas anak yang banyak saat di luar rumah membuat Ibu Cicilia kurang mempunyai waktu yang banyak bersama anaknya. anaknya sering pulang ke rumah pada sore hari bahkan terkadang malam hari karena main di rumah temannya. Ibu Cicilia hanya mempunyai waktu yang sedikit untuk bersama anakanya. Hal ini membuat Ibu Cicilia belum bisa memberikan nasihat dan arahan kepada anaknya secara maksimal. Setibanya di rumah anak sudah dalam kondisi kelelahan karena aktivitasnya di luar rumah. Saat di ajak untuk melaksanakan ibadah seperti sholat dan ngaji anak terkadang menunda-nunda dengan bilang entar dulu-entar dulu". Karena kondisi fisik yang sudah lelah terkadang kebablasan atau ketiduran dan akhirnya lupa melaksanakan sholat.

\section{Keluarga Ibu Irene}

Berdasarkan hasil wawancara penulis dengan Ibu Irene didapatkan data tentang kesulitan dalam metode yang Ibu Irene gunakan dalam mengajarkan pendidikan pendidikan agama Islam kepada anak reamajanya sebagi berikut (Wawancara, 15 Januari 2016). Segala perbuatan jika dilakukan dengan ikhlas dan kesabaran akan berjalan dengan baik. Begitu pula saat Ibu Irene mengajarkan dan mendidik agama Islam kepada anaknya. menurut beliau tidak ada kesulitan yang berarti dalam cara mendidik anaknya. Kata Bu Irene: "mas, saya itu melakukan segala sesuatu hanya buat anak. saya melakukannya penuh dengan keikhlasan”. Keihklasannya dalam memberikan perhatian dan kasih sayangnya membuatnya merasa nyaman menjalankan perannya sebagai orang tua. 


\section{Waenoful}

\section{Keluarga Ibu Maria}

Berdasarkan hasil wawancara penulis dengan Ibu Maria didapatkan data tentang kesulitan dalam metode yang Ibu Maria gunakan dalam mengajarkan pendidikan pendidikan agama Islam kepada anak reamajanya sebagi berikut (Wawancara, 18 Januari 2016). Kondisi remaja yang masih dalam perkemabangan membuat anak masih labil. Masih ada rasa malas dan perlu perhatian. menurut Ibu Maria kesulitan yang beliau alami dalam mendidik agama Islam kepada anaknya ialah anak masih santai-santai saat disuruh untuk sholat ke masjid. Ibu Maria masih perlu mengingatkan anaknya untuk sholat jamaah di masjid. Anaknya juga masih sering lupa minum berdiri. Keterbatasan waktu beliau karena menjadi guru. Membuat intensitas bertemu dengan sangat sedikit membuatnya belum bisa memberikan perhatian dan nasihat kepada anaknya secara maksiamal.

Dari penjelasan diatas tentang kesulitan orang tua mualaf dalam menggunakan metode dalam memberikan pendidikan agama Islam kepada anaknya dapat diketahui bahwa kesibukan anak yang mempunyai banyak aktivitas di luar ruah membuat orang tua mualaf memiliki keterbatasan waktu untuk memberikan pendidikan agama Islam kepada anaknya. hal tersebut membuat orang tua mualaf kurang maksimal dalam memberikan pendidikan agama Islam kepada anaknya. Kondisi anak yang masih usia remaja mebuat anak masih mempunyai sifat malas dan ikut-ikutan temannya. Anak masih memiliki jiwa untuk senang-senang dengan temannya. Hal ini yang membuat anak kadang menunda perintah orang tuanya untuk beribadah. Keterbatasan waktu karena kesibukan pekerjaan orang tua mualaf juga menjadi kesulitan orang tua mualaf dalam memberikan pendidikan agama Islam kepada anaknya. Proses pemberian pendidikan agama Islam oleh orang tua mualaf kepada anaknya butuh kesabaran dan keikhlasan juga perhatian dan kasih sayang. Segala hal yang 
dilakukan dengan hati yang ikhlas akan berjalan dengan baik dan menganggap tidak ada kesulitan walaupun sebenarnya menemui kesulitan atau hambatan.

\section{Kesulitan Orang Tua mualaf dalam memberikan Materi pendidikan Agama Is- lam kepada anaknya.}

Pelaksanaan orang tua mualaf dalam memberikan pendidikan agama Islam kepada anak remajanya ada faktor kesulitan dari materi yang diajarkan. Hal tersebut karena keterbatasan ilmu agama yang dimiliki orang tua mualaf. Berdasarkan wawancara yang dilakukan dengan para orang tua mualaf didapatkan data tentang kesulitan orang tua mualaf dalam memberikan pendidikan agama Islam kepada anak remajanya sebagai berikut :

\section{Keluarga Ibu Cicilia}

Penulis melakukan wawancara dengan Ibu Cicilia tentang kesulitan orang tua mualaf dalam memberikan materi pendidikan agama Islam kepada anak ramajanya didapatkan data sebagai berikut (Wawancara, 31 Desember 2015). Ibu Cicilia belum bisa ngaji atau membaca Al-Qur'an. Ibu Cicilia mengalami kesulitan mengajarkan membaca Al-Qur'an kepada anaknya. beliau mengatasinya dengan sejak kecil anaknya dimasukkan di TPA dan di sekolahkan di sekolah Islam. Dari segi pengetahuan ilmu agama Islam Ibu Cicilia masih minim. Beliau hanya mengajarkan materi agama Islam yang beliau ketahui. Selebihnya anak mendapatkan pengetahuan ilmu agama dari pengajian yang beliau ikuti dengan mengajak anaknya.

\section{Keluarga Ibu Irene}

Berdasarkan wawancara penulis dengan Ibu Irene didapatkan data tentang kesulitan Ibu Irene dalam memberikan materi pendidikan agama Islam kepada anak remajanya sebagai berikut (Wawancara, 15 Januari 2016). Ibu Irene menjadi mualaf 


\section{Waenoful}

saat beliau kuliah. Walaupun sejak kecil sudah diajarkan oleh almarhum ayahnya membaca Iqra, saat dewasa beliau tidak lagi belajar Iqra karena pemeluk Katolik. Saat beliau mempunyai anak pun belum bisa membaca Al-Qur'an secara lancar. Begitu juga dengan agamanya masih minim. beliau belum bisa mengajari Al-Qur'an dan ilmu agama kepada anaknya. beliau mengatasi kesulitan tersebut dengan mengundang guru ngaji ke rumah untuk mengajari anak dan beliau belajar ilmu agama dan membaca Al-Qur'an.

\section{Keluarga Ibu Maria}

Berdasarkan wawancara penulis dengan Ibu Irene didapatkan data tentang kesulitan Ibu Maria dalam memberikan materi pendidikan agama Islam kepada anak remajanya sebagai berikut (Wawancara, 18 Januari 2016). Ibu Maria belum bisa membaca Al-Qur'an. Beliau belum bisa mengajari sendiri anaknya membaca AlQur'an. Beliau mengundang guru ngaji ke rumah untuk mengajari anaknya membaca Al-Qur'an. Kondisi orang tua mualaf dari segi pengetahuan agama Islam dan praktik ibadah masih minim. Seperti dalam hal membaca Al-Qur'an. Dari ketiga keluarga mualaf yang penulis teliti. Semuanya belum bisa membaca Al-Qur'an secara lancar. Para orang tua mualaf kesulitan mengajarkan ngaji atau membaca Al-Qur'an kepada anaknya. Keterbatasan lain orang tua mualaf adalah dalam memberikan pengetahuan tentang keIslaman. Karena memang orang tua mualaf masih dalam tahap belajar tentang Islam.

\section{Analisis Implikasi Kesulitan Orang Tua Mualaf Dalam Memberikan Pendi- dikan Agama Islam Kepada Anaknya Terhadap Perilaku Keagamaan Anak.}

Kesulitan yang dialami para orang tua mualaf dalam memberikan pendidikan agama Islam kepada anaknya tidak membuat para orang tua mualaf pasrah dengan keadaan. Justru sebaliknya, para orang tua mualaf bertekad dengan sungguh-sungguh 


\section{Kesulitan Orangtua Mualaf ...

mendidik anak-anaknya menjadi manusia yang berakhlakul karimah dan berguna bagi agama, bangsa, masyarkat dan keluarga. Pengalaman para orang tua mualaf yang pernah menganut agama selain Islam membuat mereka serius dalam mendidik agama anak-anaknya agar tetap dalam aqidah Islam. Segala upaya dilakukan para orang tua mualaf untuk mendidik agama anak-anaknya. Sejak kecil para orang tua mualaf mendidik agama Islam kepada anaknya dengan pembiasaan ibadah, menyekolahkan anak-anak di sekolah Islam. Hal tersebut tentu agar anak sudah terbiasa melaksanakan ibadah dan mempunyai pengetahuan keislaman yang luas. Saat anak menginjak remaja sudah terbiasa beribadah dan mempunyai perilaku yang Islami.

Pendidikan agama Islam yang dilakukan orang tua mualaf kepada anaknya sejak dini berdampak pada perilaku keagamaan anak. proses palaksanaan pemberian pendidikan agama Islam kepada anak yang dilakukan sejak dini secara sungguhsungguh dan serius berdampak positif pada perilku keagamaan anak pada usia remaja. Perilaku keagamaan anak dapat dilihat dari beberapa dimensi perilaku keagamaannya yaitu: dimensi keyakinan, dimensi praktik / ritual keagamaan, dimensi pengalaman, dan dimensi pengetahuan keagamaan. Berikut penjelasan perilaku keagamaan anak dari para orang tua maualaf:

\section{Perilaku keagamaan anak Ibu Cicilia}

Berdasarkan hasil wawancara dengan Taufiq didapatkan data tentang perilaku keagamaan anak dari empat dimensi perilaku keagamaan sebagai berikut (Wawancara, 31 Desember 2015). Dari dimensi keyakinan, Taufiq yakin dengan adanya Allah SWT dengan melihat alam dan seisinya sebagai ciptaan Allah SWT. Dari dimensi praktik/ritual keagamaan, Taufiq menjalankan sholat wajib lima waktu. Karena faktor kesibukan di sekolah pelaksanaan sholat tidak selalu di awal waktu. Bukan hanya shalat, ibadah wajib lain seperti puasa Ramadan Taufiq menunaikannya sebulan 


\section{Waenoful}

penuh. Ibadah-ibadah sunah juga Taufiq kerjakan seperti sholat tahajud, infaq, dan lain-lain.

Dari dimensi pengalaman, Taufiq pernah merasakan dekat dengan Allah SWT. Saat itu Taufiq mempunyai banyak masalah dengan temannya di sekolah. Taufiq melaksanakan sholat tahajud dan mencurahkan permasalahannya kepada Allah SWT. Dia merasa dekat dengan Allah bisa menceritakan masalahnya kepada Allah SWT. Dari dimensi pengetahuan, Taufiq mempunyai pengetahuan agama yang cukup luas. Saat ditanya tentang ketentuan shalat dan puasa Dia dapat menjawabnya.

\section{Perilaku keagamaan Anak Ibu Irene}

Berdasarkan hasil wawancara dengan Anggita didapatkan data tentang perilaku keagamaan anak dari empat dimensi perilaku keagamaan sebagai berikut (Wawancara, 30 Januari 2016). Dari dimensi keyakinan, Anggita meyakini bahwa Allah SWT adalah satu-satunya Tuhan yang berhak di sembah. Segala permintaannya dia panjatkan hanya kepada Allah SWT. Dia juga meyakini segala sesuatunya atas kehendak Allah SWT, termasuk yang mengabulkan do'anya. Dari dimensi prakti/ ritual keagamaan, Anggita melaksanakan sholat wajib lima waktu. Pada keadaan tertentu sholat isyanya masih "bolong" tidak dikerjakan karena kelelahan. Biasanya saat kelelahan setelah melaksanakan sholat maghrib langsung tiduran dan akhirnya kebablasan. Ibadah lain seperti sholat tahajud dan sholat hajat Anggita rutin melaksanakannya karena dari kecil sudah dibiasakan dibangunkan ibunya. Anggita juga rutin infaq di sekolahnya setiap hari jum'at.

Dari dimensi pengalaman, Anggita pernah merasakan dekat dengan Allah SWT saat Anggita shalat tahajud meminta agar bisa diterima di sekolah impiannya yaitu SMA Muhammadiyah 1 Yogyakarta. Ketika Anggita mempunyai banyak 


\section{Kesulitan Orangtua Mualaf ...

masalah juga melaksanakan sholat tahajud dan saat itulah dia merasa dekat dengan Allah SWT. Karena pelaksanaan shalatnya dilakukan dengan penuh kepasrahan dan penghayatan. Dari dimensi pengetahuan, Anggita mempunyai pengetahuan agama yang cukup luas. Saat ditany tentang halal, haram dapat menjelaskannya dengan baik. Anggita juga dapat menjelaskan saat ditanya esensi dari perintah dan pelaksanaan ibadah puasa.

\section{Perilaku keagamaan anak Ibu Maria}

Berdasarkan hasil wawancara dengan Fadhil didapatkan data tentang perilaku keagamaan anak dari empat dimensi perilaku keagamaan sebagai berikut (Wawancara, 19 Januari 2016). Dari dimensi keyakinan, Fadhil meyakini adanya Allah SWT dengan melihat ciptanNya seperti langit dan bumi. Fadhil juga meyakini bahawa manusia ada yang mengawasi dan mencatat segala perbuatan manusia yaitu malakikat Raqib dan Atid. Dari dimensi praktik/ritual keagamaan, Fadhil rajin melaksanakan sholat wajib lima waktu, bahkan sebagian besar sholatnya dilaksanakan berjamaah di masjid karena rumahnya dekat dengan masjid. Ibadah puasa wajib saat Ramadan juga fadhil melaksanakannya satu bulan penuh karena sejak usia 5 tahun sudah dilatih orangtuanya berpuasa. Fadhil membiasakan bersedekah kepada siapa saja yang waktu dia jumpai dan sekiraanya membutuhkan pertolongan seperti pengemis di jalan.

Dari dimensi pengalaman, Fadhil merasakan dekat dengan Allah SWT saat dia masih di pondok pesantren. Saat itu Fadhil melaksanakan sholat tahajud karena ada sesuatu yang dia inginkan. Dia melaksanakan shalat dengan khusyu dan merasa benar-benar dekat dengan Allah SWT. Dari dimensi pengetahuan, Fadhil mempunyai pengetahuan agama Islam yang cukup luas. Fadhil dapat menjelaskan tentamg ketentuan ibadah, rukun Islam dan rukun Iman. Dari penjelasan tentang perilaku keagamaan anak dari para orang tua mualaf dapat diketahu bahwa: Dari 


\section{Waenoful}

simensi keyakinan, anak memiliki keyakinan yang kuat terhadap Allah SWT sebagai satu-satunya Tuhan semesta alam. Menurut mereka keyakinan terhadap Allah SWT didapat dari pengamatan akan ciptaan-Nya seperti langit dan bumi dan juga kasih sayang Allah SWT yang senantiasa diberikan kepada mereka atas doa yang mereka panjatkan.

Dari dimensi praktik / ritual, anak secara istiqomah melakukan sholat lima waktu meskipun pelaksanaannya tidak di awal waktu karena kesibukan di sekolah. Sholat sunah seperti sholat malam juga diamalkan anak. walaupun pelaksanannya tidak rutin. Anak juga secara rutin setiap hari jum'at menyisihkan uang jajannya untuk infaq di masjid. Dari dimensi pengalaman, ketika anak mengalami masalah pribadi di sekolah atau temannya. Mereka memiliki ritual solat malam untuk curhat dengan Allah SWT meminta ketenangan dan solusi atas masalah mereka. Saat itulah mereka merasa dekat dengan Allah SWT. Dari dimensi pengetahuan, anak dapat menjawab ketika ditanya tentang ketentuan solat dan puasa. Anak juga dapat menjelaskan tentang rukun Iman, dan rukun Islam dan juga dalam perkara halal, haram, sunah, dan syubhat. Dari dimensi pengetahuan mereka memiliki pengetahuan keIslaman yang cukup luas.

\section{Kesimpulan}

Berdasarkan pembahasan dan analisa pada bab sebelumnya maka dapat diperolah kesimpulan sebagai berikut: Orang tua mualaf memberikan pendidikan agama Islam kepada anak remajanya, pada prosesnya mengajarkan: tentang tauhid, ibadah mahdoh dan ghoiru mahdoh yang meliputi shalat, puasa, zakat, dan bergaul dengan lingkungan sesuai dengan ajaran Islam. Metode yang digunakan orang tua mualaf dalam memberikan pendidikan agama Islam kepada anak remajanya meliputi: memberikan contoh (keteladanan), cerita (kisah), nasihat, motivasi dan 


\section{Kesulitan Orangtua Mualaf ...

ancaman. Kesulitan yang dialami orang tua mualaf dalam memberikan pendidikan agama Islam kepada anaknya, diantaranya: orang tua mualaf tidak bisa memberikan pengajaran pengetahuan tentang Islam karena minimnya ilmu pengetahuan agama orang tua mualaf, orang tua mualaf tidak bisa mengajarkan membaca Al-Qur'an kepada anaknya karena orang tua mualaf belum bisa membaca Al-Qur'an dengan baik dan benar, kesibukan kegiatan anak remajanya di luar rumah menjadikan intensitas orang tua mualaf dalam memberikan nasihat kepada anaknya kurang maksimal, anak usia remaja memiliki kondisi psikologis yang labil membuat anak masih menunda perintah orang tua, terutama saat diperintah melaksanakan ibadah shalat. Kesulitan orang tua mualaf dalam memberikan pendidikan agama Islam kepada anaknya yang remaja tidak berdampak buruk terhadap perilaku keagamaan anak. Hal tersebut dikarenakan orang tua mualaf dapat mengatasi kesulitan tersebut dengan mendatangkan guru ngaji ke rumah dan menyekolahkan anak di sekolah Islam.

\section{Saran-saran}

Berdasarkan temuan yang telah dijelaskan pad bab sebelumnya maka saran yang diberikan sebagai berikut: Untuk para guru PAI yang memiliki peserta didik yang orang tuanya mualaf dapat memberikan bimbingan keIslaman yang lebih intens kepada peserta didik. Hal tersebut dikarenakan saat peserta didik berada di dalam lingkungan keluarga, orang tua mualaf belum dapat memberikan pendidikan agama Islam secara baik kepada anaknya karena keIslamannya yang belum mapan. Untuk para Da'i yang berkecimpung dalam bidang pembinaan mualaf agar lebih intensif dalam melakukan pembinaan terhadap para orang tua mualaf. Terlebih pada pembinaan masalah ibadah, karena orang tua mualaf belum bisa mengajarkan membaca Al-Qur'an kepada anaknya, belum lancar dalam bacaan dan gerakan shalat, 


\section{Waenoful}

dan masih sedikit pengetahuan keIslamannya.

Untuk para orang tua mualaf, walaupun dalam kondisi keterbatasan dalam suatu hal, orang tua mualaf tetap harus dan wajib memberikan pendidikan agama Islam kepada anaknya. orang tua mualaf agar selalu istiqomah dalam memberikan pendidikan agama Islam kepada anak. karena pendidikan agama Islam penting bagi anak sebagai sarana membentuk manusia yang berakhlaqul karimah. Untuk peneliti selanjutnya agar dapat mengembangkan kajian tentang pelaksanaan pendidikan agama Islam dalam keluarga.

\section{Daftar Pustaka}

Abdurrahman, Syaikh J, 2013. Islamic Parenting Pendidikan Anak Metode Nabi, Solo: Aqwam.

Alwi, Muhammad Wahidan wawancara oleh Waenoful, 23 November 2015.

Ancok, Djamaludin dan Fuat Nashori Suroso, 2011. Psikologi Islam (solusi Islam atas problem-problem psikologi), Yogyakarta: Pustaka Pelajar.

Anwar, Saifudin, 1999. Metode Penelitian, Yogyakarta: Pustaka Pelajar.

Arifin, Bambang Samsul, 2008. Psikologi Agama, Bandung: Pustaka Setia.

Awwad, Jaudah M., 1995. Mendidik Anak Secara Islam, Jakarta: Gema Insani Press.

Basrowi dan Suwandi, 2009. Memahami Penelitian Kualitatif, Jakarta: Rineka Cipta.

Dahlan, Zaini, 2014. Qur'an Karim dan Terjemahan Artinya, Yogyakarta: UII Press.

Darajat, Zakiah, 1991. Pendidikan Islam dalam Keluarga dan Sekolah, Bandung: PT. 


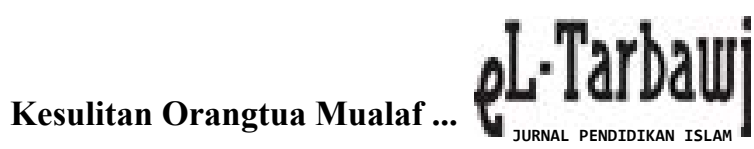

Remaja Rosdakarya. , 1997. Pembinaan Remaja, Jakarta: Bulan Bintang.

Dhetasari, 2015. "Menjemput Kasih, Meraih Hidayah", Republika, 8 November 2015 .

Dister, Nico Syukur, 1998. Pengalaman dan Motivasi Beragama, Yogyakarta: Kanisius.

Ghuddah, Abd. Al-Fattah Abu, 2005. 40 Strategi Pembelajaran Rasulullah, penerjemah: Sumedi dan R. Umi Baroroh, Yogyakarta: Tiara Wacana.

Gunawan, Heri, 2014. Pendidikan Islam Kajian teoritis dan Pemikiran Tokoh, Bandung: Remaja Rosdakarya.

Harini, Sri., dkk, 2003. Mendidik Anak Sejak Dini, Yogyakarta: Kreasi Wacana.

Jalaluddin, 2012. Psikologi Agama, Jakarta: Raja Grafindo Persada.

Malik, Ridwan, 2013. Yuk Ajarkan Akhlak dan Ibadah Kepada Anak-anak Kita, Bandung: Mizania.

Mansur, 2011. Pendidikan Anak Usia Dini dalam Islam, Jakarta: Pustaka Pelajar.

Muchsin, Bashori., dkk., 2010. Pendidikan Islam Humanistik, Bandung: Refika Aditama.

Muhammad, Syaikh, 2006. Seni Mendidik Anak, Jakarta: Al-Kautsar.

Mujib, Abdul dan Jusuf Mudzakkir, 2008. Ilmu Pendidikan Islam, Jakarta: Kencana. Munawwir, Ahmad W., 1997. Al-Munawwir Kamus Arab - Indonesia, Surabaya: Pustaka Progressif. 


\section{Waenoful}

Poerwadarminta, W.J.S., 1976. Kamus Umum Bahasa Indonesia, Jakarta: PN Balai Pustaka.

Purwanto, Ngalim, 2000. Ilmu Pendidikan Teoritis dan Praktis, Bandung: PT Remaja Rosda Karya.

Qaraati, Mohsen, 2005. Tafsir Untuk Anak Muda (Surah Luqman), Penerjemah: M. Ilyas, Jakarta: Al-Huda.

Rachman, Fauzi, 2011. Islamic Parenting, Jakarta: Erlangga.

Ramayulis, 2007. Psikologi Agama, Jakarta: Kalam Mulia.

Suharsaputra, Uhar, 2012. Metode Penelitian Kuantitatif, Kualitatif, Dan Tindakan, Bandung: Revika Aditama.

Sutrisno, Markus, wawancara oleh Waenoful, 17 November 2015.

Tafsir, Ahmad, 1995. Pendidikan Agama dalam Keluarga, Bandung: PT. Remaja Rosdakarya.

Takariawan, Cahyadi, 2001. Pernik-Pernik Rumah Tangga Islami, Surakarta: Era Intermedia.

Zulkifli L., 1995. Psikologi Perkembangan, Bandung: Rosdakarya. 